University of Louisville

ThinkIR: The University of Louisville's Institutional Repository

Electronic Theses and Dissertations

$5-2012$

\title{
Emotional labor in a gendered occupation : the work of a female funeral director.
}

Allison Scott Pruitt

University of Louisville

Follow this and additional works at: https://ir.library.louisville.edu/etd

\section{Recommended Citation}

Pruitt, Allison Scott, "Emotional labor in a gendered occupation : the work of a female funeral director." (2012). Electronic Theses and Dissertations. Paper 1160.

https://doi.org/10.18297/etd/1160

This Master's Thesis is brought to you for free and open access by ThinkIR: The University of Louisville's Institutional Repository. It has been accepted for inclusion in Electronic Theses and Dissertations by an authorized administrator of ThinkIR: The University of Louisville's Institutional Repository. This title appears here courtesy of the author, who has retained all other copyrights. For more information, please contact thinkir@louisville.edu. 


\title{
EMOTIONAL LABOR IN A GENDERED OCCUPATION: THE WORK OF A
}

\author{
FEMALE FUNERAL DIRECTOR
}

\section{By}

\author{
Allison Scott Pruitt \\ B.S., University of Louisville, 2010 \\ A Thesis \\ Submitted to the Faculty of the \\ College of Arts and Sciences of the University of Louisville \\ in Partial Fulfillment of the Requirements \\ for the Degree of
}

Master of Arts

Department of Sociology

University of Louisville

May 2012 
EMOTIONAL LABOR IN A GENDERED OCCUPATION: THE WORK OF A FEMALE FUNERAL DIRECTOR

By

Allison Scott Pruitt

B.S., University of Louisville, 2010

A Thesis Approved on

April 23, 2012

by the following Thesis Committee:

James. K. Beggan, Thesis Director

Cynthia Negrey

Laurie Rhodebeck 


\begin{abstract}
EMOTIONAL LABOR IN A GENDERED OCCUPATION: THE WORK OF A FEMALE FUNERAL DIRECTOR
\end{abstract}

\author{
Allison Scott Pruitt
}

April 23, 2012

Hochschild (1983) stated that emotional labor has unique consequences for women. However, most studies of these consequences have been situated in feminized occupations which have wage penalties and little upward mobility (see Sweet and Meiksins, 2004). This poses a problem as it may be difficult to tease apart what stressors are the result of emotional labor and which are a part of the broader issues of feminized work. The present research suggests that the funeral industry is a unique context for the study of women's emotional labor, as it is a numerically male dominated profession (BLS, 2010). Using semi-structured, in-depth interviews with thirteen female funeral directors, the present research explored how women connected work roles and societal norms. The results suggest that beliefs in gender essentialism, or beliefs in other's essentialism, may influence how women experience and perform emotional labor. 


\section{TABLE OF CONTENTS}

\section{PAGE}



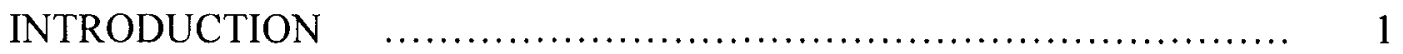

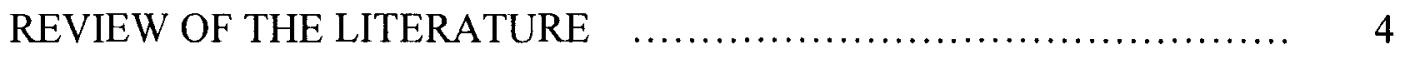

Occupational Sex Segregation $\quad$........................... 5

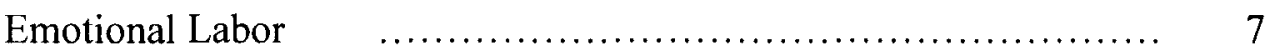

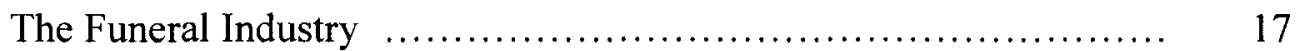

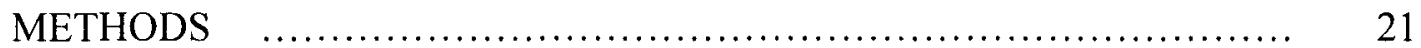

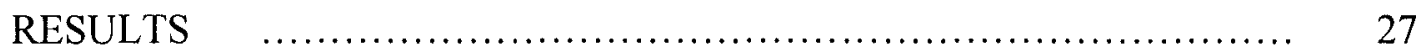

Gendered Nature of Work $\quad$................................... 33

Belief in Essentialism ........................................ 42



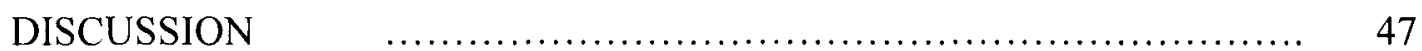

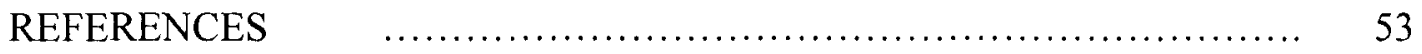

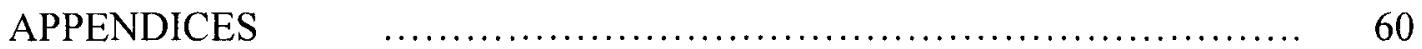






\section{CHAPTER I}

\section{INTRODUCTION}

Despite large numbers of women entering the workforce since the 1960's, women are still largely crowded into a relatively small number of occupations (Sweet and Meiksins, 2008). A common explanation of this phenomenon is that women are moved into certain fields based on beliefs and stereotypes about the nature of women (Charles and Grusky, 2004). The most prominent of these essentialist notions is that women possess an innate skill for interpersonal interaction (Fitzsimmons, 2002), particularly interactions that involve conveying a sense of nurturing (Kennelly, 2006).

In her conception of emotional labor, Hochschild (1983) noted that women, more often than men, are employed in occupations that require them to act caring and nurturing toward customers. Even nearly thirty years later, this general trend still continues today (Sweet and Meiskins, 2008). Additionally, Hochschild (1983) noted that emotional labor had special significance for women, and therefore heightened consequences. However, a discussion of how essentialism may affect women's overrepresentation in jobs that require emotional labor is distinctly lacking. 
Further, Hochschild has been criticized for choosing to examine professions that not only have the characteristic of being dominated numerically by males or females, but also for choosing occupations that were "emotionally gendered" as well (Erickson and Ritter, 2001). In essence, what Hochschild examined was women working in female dominated occupations performing stereotypically feminine work. The distinction between the gender composition of occupations and the types of work required in them has been recognized in the literature concerning what constitutes a "gendered" occupation. Recognizing the distinction, Britton (2000) noted that jobs can be gendered by either the numerical composition of the occupation field, or the way in which traits required for the job are typically designated as masculine or feminine.

Brittton (2000) extended this argument to include that the numerical composition males and females in occupations and the gendered traits required of those jobs do not always align. The notion of the "transgendered" occupation encompasses this seeming disparity. In a study of this non-alignment, Britton (1999) examined women working as prison guards in women's facilities, defining this as women working in a female dominated occupation that actually required stereotypically male traits.

Despite the similarities between the literature on emotional labor and gendered occupations, the two concepts are rarely studied in conjunction with one another. Just as Hochschild (1983) did not qualify that that her work on emotional labor was situated in a feminized occupation regardless of the emotional labor performed, Britton (2000) did not incorporate a discussion of emotional labor in her work on prison guards as a transgendered occupation, a field typically described as demanding a high amount of emotional labor, although typified to males. 
The experience of women working in numerically female dominated occupations, whether performing tasks stereotyped to males or females, is well documented. The experience of women working in male dominated fields, while still performing stereotypically feminine traits, is under examined, or altogether absent from the literature. Although this occurrence would seemingly contradict findings that men do not wish to work in fields that express feminine traits (Sweet and Meiksins, 2004), and therefore would not numerically dominate in an occupation that requires emotional displays or caring and nurturance, at least one such occupation arguably fits this criteria. Funeral directing has historically been a male dominated industry. Although more women have moved into the field in recent years, as of 2010 only $23 \%$ of all funeral directors were females (BLS, 2010). Despite this, funeral directing requires several stereotypically feminine skills. Funeral directors must as a caregiver the family of the deceased (Bailey, 2010), as well as display an overall compassionate demeanor (BLS, 2010).

The present study examines the experiences of women working in the funeral industry, as an occupation that requires both high amounts of emotional labor and has the distinction of being a "transgendered" occupation. The aim of this exploratory research is to contribute to the literature in two ways. First, the present research may highlight the consequences of emotional labor that are unique to women, if any, outside of the generally accepted consequences of working in a feminized occupation. Second, the present research will explore how gender essentialism affects job preference, even when the job generally excludes females. 


\section{CHAPTER II}

\section{REVIEW OF THE LITERATURE}

The experience of work for women has remained an important concept in the social sciences since the 1970 's. Despite both informal and formal calls for gender equality, actual status differences between men and women on the job still persist (BesenCassino, 2008).

Women are over-represented in occupational fields that focus on customer interaction (Sweet and Meiksins, 2008). These types of jobs generally require a significant amount of emotional labor, the requirement that the worker display certain feelings, generally to reassure customers of positive emotions (Hochschild, 1983). Hochschild (1983) hypothesized that emotional labor has unique consequences for women, namely in terms of increased stress. Although employment in fields with high levels of emotional labor have been found to be a significant contributing factor to the overall wage gap between men and women (Glomb, Kammeyer-Mueller, \& Rotundo, 2004), increased stress, or "burnout", from emotional labor for women remains a debatable occurrence (Noor and Zainuddin, 2011; Erickson and Ritter, 2001). 
The ambiguity of research on burnout from emotional labor for women may be at least partially explained in the nature of the occupations being examined. For the most part, studies on emotional labor for women have focused on women working in female dominated occupations. That is, women performing a stereotypically feminine role in a feminized job. Some scholars have argued that the consequences for women in the workplace are tied to a general devaluation of women's work, independent of the actual features of the job itself (Sweet and Meiksins, 2008). From this it could be argued that the consequences of emotional labor outlined by Hochschild and subsequent researchers may be better explained by women working in feminized occupations rather than a unique consequence of emotional labor.

While the concept of emotional labor is defined and researched in terms of the beliefs about feminine and masculine activities, and it is widely accepted that the consequences of emotional labor are disproportionate to women, it is rarely studied in settings outside of feminized occupations. This study uses funeral directing as a context to link emotional labor and the gendering of work. Funeral directing provides a unique context because it involves a significant amount of emotional labor, but is numerically dominated by men. This work will focus on the way that employees define emotional labor in regards to gender, and the perceived consequences of performing emotional labor in a setting that is not a feminized occupation.

\section{Occupational Sex Segregation}

Egalitarian values towards women have rapidly spread throughout many facets of American culture, including the workplace (Banks and Milestone, 2011; Smith, 1999). 
Despite rising numbers of females obtaining college degrees and joining the workforce, women are still largely crowded into small number of occupations such as nursing or teaching (Sweet and Meiksins, 2008; Charles \& Grusky, 2004). One of the more accepted reasons why such segregation exists in work sectors is the essentialist belief that women are highly skilled in interpersonal interaction (Fitzsimmons, 2002).

The effects of gender essentialism on organizational and occupational segregation can be thought of as both on an organizational and employer level, as well as choice by the individual employee. Many essentialist views are embedded in institutional practice and internal personnel systems through policies that favor placing men in certain positions and women in others, with women generally being favored in customer interaction roles (Charles and Grusky, 2004). This also carries down to the level of the individual managers and supervisors. If an individual employer has internalized gender essentialist stereotypes, they may hire, fire, and promote based on those beliefs (Reskin and Roos, 1990). This can occur without an awareness of outright discrimination on the part of the employer (Reskin, 2000) and employers often do not notice women's actions that do not conform to gender expectations (Fiske, 1998).

Employees may also engage themselves in practices that reify gender segregation in work roles. Young girls may also internalize essentialist beliefs that leads them to express a preference for work in certain occupations (Charles and Grusky, 2004), such as those involving emotional labor. This internalization is usually subconscious, but still creates gender segregation in work preferences and other facets of life (Xie and Shauman, 2003). A component of women expressing a preference for certain roles may also be tied to a self-evaluation of their skills. Essentialist beliefs that women internalize may lead 
them to believe they more qualified for certain work positions, and avoid male-typed employment, regardless of the objective qualifications for the job (Charles and Grusky, 2004). It is important to note that perceived essentialist thinking in others can also affect women's choices. Exposure to essentialist thinking, even when the individual does not personally believe it, can lead women accept status inequality (Morton, Postmes, Haslam, and Hornsey, 2009). Therefore, it is possible that women may express preferences for certain work roles based on the perceived essentialist thinking of others, rather than their own beliefs about gender roles.

\section{Hochschild's Concept of Emotional Labor}

Interpersonal interaction, with the essentialist belief that women excel in areas of personal service dealing with nurturance (Fitzsimmons, 2002), can also be conceptualized as a form of emotional labor. Hochschild (1983) first defined emotional labor as requiring one to "induce or suppress feeling in order to sustain the outward countenance that produces the proper state of mind in others..." (Hochschild, 1983, 7). Emotional labor is different than emotion management because it is performed for wages in the public sphere (Wharton, 1993). Hochschild (1983, Appendix C) identified a list of fortyfour occupations, including nurses, bank tellers, and clergy, that involve significant amounts of emotional labor, as well as highlighting the gender segregation in these occupational fields by showing the disproportional number of women in many of these occupations. The central similarity of these occupations is that emotional displays are an 
essential job function, and performing the required emotion must be done in such a fashion that the customer believes it is genuine (Hochschild, 1983).

Hochschild (1983) stated that there are three main characteristics that jobs requiring high amounts of emotional labor have in common: frequent voice or facial contact with the public, the need to produce an emotional state in another, and the ability of the employer to control the emotional displays of the worker. Hochschild estimated that about one-third of all jobs, and half of women's jobs, require substantial amounts of emotional labor, while more recent research has suggested that emotional labor is involved in the majority of all workplace communication in a variety of fields (Miller and Koesten, 2008; Mann, 1999).

\section{Gender and Emotional Labor}

Hochschild (1983) recognized the link between emotional labor and gender by estimating that nearly half of employed women were in jobs involving significant amounts of emotional labor. Hochschild (1983) stated that emotional labor "has special relevance for women" and that "women more than men have put emotional labor on the market, and they know more about its personal costs" (p 11). This argument is positioned in the fact that women have less social power and independent earnings than men (Hochschild, 1983). Hochschild (1983) outlined four "consequences" of emotional labor relative to women's subordinate status. First, women have fewer resources than men and therefore turn their feeling into a marketable commodity. Second, due to factors of socialization, Hochschild (1983) stated that women are the "flight attendants" (e.g. kind, caring, supportive) while men are the "bill collectors" (e.g. anger, demanding). 
Although both "flight attendants" and "bill collectors" are still forms of emotional labor, women are more often placed in the roles of emotional labor that demand "being nice" as an essential job function. Third, because women are in a lower social stratum, they can become victims of the feelings of others. Hochschild (1983) found that female flight attendants were more often victims of verbal abuse from disgruntled passengers than their male counterparts. Finally, women are more likely to use emotional labor in the form of sexual charm and relational skills as a defense mechanism, and become estranged from those attributes of femininity. Hochschild concludes "women and men come to experience emotion work in different ways" (p. 164) based on biological sex alone, and evidence suggests that women engage in more frequent emotion management than men.

Much of the research on the relationship between emotional labor and gender has focused on the lack of protection women have as a result of their lower social status. Hochschild (1983) hypothesized that women are more prone to negative socialpsychological consequences of emotional labor because of their lower social power in comparison to men. Research has tried to confirm that point, however, the results have been mixed. While Wharton (1993) found few gender differences in job satisfaction or job related stress, she claimed this finding could be spurious due to the relative oversampling of women to men, not because actual differences did not exist. In other research, evidence has been found that women more often have to hide negative emotions at work, but this relationship was not found to be significantly related to burnout (Erickson and Ritter, 2001). Research has shown that women's emotion work in the family setting can lead to increased burnout at work (Erickson and Wharton, 1995), but this finding is unclear as to whether or not the emotional labor of the job itself is 
contributing to the burnout. Glomb et al. (2004) confirmed that emotional labor demands on the job are higher for occupations dominated by females, but did not relate this finding to burnout or question if men in the same jobs were subject to the same degree of emotional labor demands. Further, Bhave and Glomb (2009) found that men in jobs involving high amounts of emotional labor experienced a "wage penalty" as compared to men in jobs with low amounts of emotional labor, and this effect did not hold true for women. Despite this finding, Maume (1999) argued for the existence of a "glass escalator" in his finding that men in female-typed occupations were more likely to be promoted to management.

In all, the relationship between gender, emotional labor, and negative socialpsychological consequences, such as burnout and stress, remains unclear at best. However, it is possible that a relationship between gender, emotional labor, and negative experiences may be mediated by essentialist beliefs about women, whether on the part of the employer or the employee. For instance, Bhave and Glomb (2009) found that men and women were equally willing to be employed in jobs involving high amounts of emotional labor, but opportunities to get hired in these jobs were actually higher for women, suggesting that men have a structural limitation in being hired in feminized work. Without opening a discussion of the quality of these jobs (i.e. pay, benefits, etc.), it is possible that women performing emotional labor are more often employed in feminized occupations, and the employer demands of emotional labor placed on women in these jobs are directly related to the stereotypes held about the nature of women (Hochschild, 1983). 
Hochschild (1983) stated women "are thought to manage expression and feeling not only better but more often than men do" (p. 164). In the occupations where emotional labor is taking place, women may come to believe that they are better at emotional labor than men, in effect supporting the stereotypes of gender essentialism. Although there is no research examining this question directly, findings in previous research show evidence of exactly this. Erickson (2004) found that female servers believed that they were better at dealing with customers than men because women were more emotional. Research on nurses shows that many women did not transfer to mental health fields because the physical work was better suited for men and empathetic work fit women's abilities more (Gray, 2010). Likewise, Irvine and Vermilya (2010) found evidence of "women stereotyping other women" (p. 74) to be more caring and sensitive in a case study of veterinarians.

Erickson and Ritter (2001) recognized the link between emotional labor and the context in which the work was taking place by stating that Hochschild not only selected jobs that involved emotional labor, but jobs that were "emotionally gendered" (p.147). This research recognizes the distinction between the gendering of the jobs themselves separate from the numerical composition of men and women in those jobs. A great deal of the research on emotional labor, including the work of Hochschild, focuses on feminine-types emotional labor in female dominated jobs. 


\section{Gendered Occupations}

In outlining the ways that occupations can be seen as gendered, Britton (2000) also separated the stereotypes related to the work that was being done and the demographics of men and women in a given occupation. She outlined three ways that occupations can be seen as gendered. The first is the idea that bureaucratic organization is inherently gendered. This approach rests on the argument that bureaucratic hierarchy is defined in reference to masculine traits and emphasizes power and inequality (Britton, 2000). The second definition is the extent to which men or women numerically dominate the occupation. Hochschild (1983) uses this approach when she outlines that the fortyfour occupations identified as having significant amounts of emotional labor are generally female dominated occupations. The third approach of gendering is the extent to which the occupation or organization is "symbolically and ideologically described and conceived in terms of a discourse that draws on hegemonically defined masculinities and femininities" (Britton, 2000, p. 420). Although Hochschild (1983) recognized that activities can also be seen as gendered by pointing out that women are more often put into emotional labor roles that require cooperativeness, while men are placed into jobs that draw on aggressiveness, she chose to analyze an occupation that was both female dominated and feminine typed.

It is widely accepted that feminine typed-work is devalued in comparison to maletyped work (Levanon, England, and Allison, 2009; Alksins, Desmarais, and Curtis, 2008; Sweet and Meiksins, 2008) and that female dominated jobs generally have less paths of upward mobility and wage increases (Charles and Grusky, 2004). From this, it could be argued that the occupations that have been researched in studies of emotional labor, such 
as flight attendants and restaurant servers, may have consequences that are not necessarily unique to the performance of emotional labor, but rather a part of the penalties associated with women's work more generally. Therefore, it may be important to research women's performance of emotional labor in a context that is not an otherwise feminized occupation.

\section{The Transgendered Occupation*}

The relative number of men and women in an occupation and the stereotypical sex roles assigned to those positions do not always clearly correlate. Britton (2000) suggested that there are "transgendered occupations" where certain fields may be "dominated by members of one sex that are actually gender typed in an opposite way" (p. 424). She suggests that studying these occupations may give researchers insight into the ways that gender norms at work are maintained, and the way this affects worker identity. A prominent example of a transgendered occupation is prison guards in women's facilities. Women constitute the numerical majority of officers in women's prisons, leading most to argue that it fits the "majority rules" definition of a feminized occupation (Britton, 2000). However, evidence shows that women guards do not feel like their work is feminized, and policies in place do not make women's prison's more lenient in the nature of the work as compared to men's prisons (Britton, 1999).

\footnotetext{
*Editorial comments have indicated that the term "transgendered" referencing occupations may be confusing. The author notes that the term "transgendered" has a different meaning in the literature concerning sexuality. The term "transgendered occupation" as used in the present research is taken from the original use and meaning of the term by Dana Britton (2000) and subsequent citations of her article.
} 
A more recent study reveals the connection between emotional labor and the transgender occupation, shedding light on the way that gender norms are maintained. Irvine and Vermilya (2010) conducted interviews with female veterinarians, looking at the ways that masculinity was maintained in the occupation despite having a numerical majority of females. One respondent in this work described veterinary medicine as "emotional all the way around" and frequently having to "force herself to be calm" (Irvine and Vermilya, 2010, p. 67). Although this research was not specifically analyzing emotional labor, the authors conclude that hegemonic masculinity is maintained in the field because women (despite having a numerical majority) separate themselves from and deny emotion work, stating that emotions and professionalism are not compatible.

However, this research focused on a numerically female occupation that forced someone to separate themselves from stereotypically feminine traits. The present research aims to explore how women define stereotypically feminine role in spite of a male majority in their occupation.

\section{Emotional Labor in a Gendered Organization}

Although there is very little research directly linking the concepts of emotional labor and gendered organizations, Suzanne Franzway (2000) examined the connection in her research on women in labor union reform movements in Australia. In her research she found that women in the union movements were type-cast to take care of others experiencing stress and needing support as a result of political movements, however the women were not as powerful in political discourses regarding decision making. The 
women began to think of their emotional labor in terms of expressing traditionally feminine character traits for the movement's political gain. Here, women performing emotion work in an otherwise male-dominated movement still adopted stereotypically feminine traits. However, these women did feel empowered by the work they were doing, despite recognizing the limitations of their ability to contribute within the maledominated and "macho" typed unions (Franzway, 2000).

Other research has followed more closely to the original work of Hochschild (1983) by examining women's emotional labor in feminized occupations. Research on food servers revealed that there are two main strategies servers may use to cope with the high levels of emotional labor in the occupation: investment and detachment (Erickson, 2004). Detachment is defined in terms of emotional dissonance, a recognition that there is a separation between the emotional display and genuine feelings of the self (Erickson, 2004). Investment is defined as insistence that interactions with customers are meaningful (Erickson, 2004). In a study of fifteen food servers in an independently owned restaurant, Erickson (2004) found that managers preferred to hire women due to an essentialist belief that they were more likely to utilize investment strategies and express genuinely felt emotions to customers. In turn, women working in this establishment did choose emotional investment strategies more often than men, therefore reinforcing the stereotype that women were of more nurturing character with customers.

Research on the emotional labor of nurses has found similar themes. Gray (2010) found that the industry promoted images of the nurse as a female motherly caregiver. Female nurses were believed to possess an innate ability to be caregivers. Other nurses, both male and female, expressed that male nurses belonged only in mental health fields, 
due to more aggression and physical strength required in the field (Gray, 2010). This research begins to highlight perceived gender differences within an occupation that has both masculine and feminine typed job requirements, a theme that the present research also investigates.

\section{A Contextual Approach to Emotional Labor}

Ashforth and Humphrey (1993) proposed an alternate conceptualization of emotional labor to explain the experience of burnout that begins to acknowledge the context in which work is taking place. They argue that the stronger the correlation between the expectations of one's emotional labor and societal norms, the more the worker will be able to positively internalize their emotional labor and work role. In this sense, women who work in fields requiring them to display caring and nurturance should express a preference for emotional labor because it correlates strongly to societal norms about the nature of women.

Many service jobs require positive, supportive attitudes that may be so typed towards expressing femininity that men may reject the work role entirely. Nixon (2009) found that many unemployed men would not accept jobs in the service sector because it violated how they defined their masculinity and they felt they were not capable of expressing and controlling their emotions in economically desired ways. Similarly, research on tour reps show that both men and women employed in the industry consider the job to be both women's work and a feminized profession (Guerrier and Adib, 2004). Just as Gray (2010) found that nursing promotes images of mothering female workers, 
Allison, Beggan and Clements (2004) found that people have favorable impressions of female nurses but frown upon male nurses. In this analysis, male nurses were regarded as too feminine, and this disdain was rooted in people's belief that men should not eschew their masculinity (Allison et al., 2004). Research such as this may explain why essentialism influences men's preference for work outside of female dominated occupations, but does not highlight why women may still express a preference for work in a male-dominated field.

\section{On the Funeral Industry}

Caring for the dead has always had ties to beliefs about the nature of men and women. Before hospitals and medical knowledge were prominent features of society, women generally cared for the dying and dead as part of the caregiving role (Fromme, Drach, Tolle, Ebert, Miller, Perrin, \& Tilden, 2005). Around the turn of the twentieth century, funerals became a business and took place outside of the home and family. With this change, women were no longer regarded as caregivers to the dead. In the earliest available data from 1951 , only about $4.5 \%$ of funeral directors were female (Occupational Outlook Handbook, 1951). Women were (and are still) regarded as being too physically weak to handle bodies and too emotionally fragile to be exposed to embalming rooms (Cathles, Harrington, \& Krynski, 2010). Even as recently as 2000, male funeral home owners have gone on record citing these as reasons to justify denying women apprenticeships (Wong, 2000). Today, only about $23 \%$ of all funeral directors are female (BLS, 2010). 
Emotional Labor in the Funeral Industry

Parsons (2003) argued that the funeral director is the primary caregiver to grieving families. According to the Occupational Outlook Handbook, a funeral director "honors the deceased and addresses the spiritual needs of the family" and must have "a compassionate demeanor" (BLS, 2010). Thus, funeral directing meets Hochschild's (1983) criteria for defining a job as high in emotional labor because: a) the funeral director has frequent facial and voice contact with clients, at least for the period of time that planning and services are taking place; b) they must act with compassion to the family, and make the family feel as at ease as possible; and c) the funeral director is asked to display certain feelings as a result of his or her job position.

However, the funeral director occupies the awkward position of being both a caregiver and a salesperson to the family of the deceased. There is always face-to-face work with the client, and this involves both a sales angle in terms of costs, but also an explicit expression of compassion to the client (Bailey, 2010). The aspects of sales and caregiving are generally considered not compatible. Howarth (1996) asserted that although funeral directors may be caring people, the ultimate concern is actually profit. However, in an analysis of female funeral directors, Bailey (2010) found that the directors were ultimately motivated by care and her sample described feelings actual sympathy for the families that was being expressed. 
Funeral Directing in a Gendered Framework

Sexual discrimination against women in the funeral industry is noted in the literature. In some instances, this is attributed to individual beliefs about the abilities of women (Wong, 2000). Others, however, have suggested that the legal qualifications of funeral directing in certain states, such as the requirement that funeral directors also be licensed embalmers, act as a structural barrier to keep women out of the profession (Cathles et al., 2010). Despite some growth in the number of female funeral directors, the occupation is largely male dominated. However, both official sources and funeral directors themselves generally describe the work in terms of caregiving and displays of compassion, traits generally labeled as feminine.

For these reasons, it is possible that funeral directing fits Britton's (2000) definition of a transgendered occupation: despite being numerically male, funeral directing requires skills typically typed as feminine. From the social-identity approach of emotional labor (Ashforth and Humphrey, 1993), where occupational norms may be internalized, it is possible that women working as funeral directors (as a transgendered occupation) may express essentialist beliefs as a way of validating their position in the organization.

\section{The Present Research}

It has long been recognized that most front-line service occupations that involve high amounts of emotional labor qualify as "feminized" professions (Hochschild, 1983). 
Many of the skills that service work requires perpetuate gender stereotypes and are regarded as natural, feminine qualities (Nickson and Korzynski, 2009).

From the social-identity approach of emotional labor (Ashforth and Humphrey, 1993), the social environment in which emotional labor is performed affects the workers' experience of the work. If this is taking place in a gendered occupation, where stereotypes about women are exercised in a fashion consistent with the underlying beliefs in gender essentialism, it would be difficult to separate consequences of emotional labor from the consequences of working in a feminized occupation. By analyzing the funeral industry, the present research attempts to separate feminized emotional labor from a gendered work context. This may highlight the unique negative consequences of emotional labor for women separate from the consequences of working in a gendered occupation. Consistent with previous literature on gender essentialism and work segregation (see Charles and Grusky, 2004), women in performing emotional labor may come to not only express a preference for the role, but also evaluate their work performance positively. Thus, women in the funeral industry may simultaneously have a negative work experience as a result of being females in a male dominated profession, but also positively evaluate their work role because it closely coincides with gender norms. By situating the funeral industry as a transgendered occupation, the present research also aims to explore how gender essentialism can influence preference for work and work roles, even in a male-dominated occupation. 


\section{CHAPTER III}

\section{RESEARCH METHODOLOGY}

Although there is an ample amount of literature examining gender differences in both the effects and performance of emotional labor (see Wharton, 1993), very little research situates this in terms of occupational sex segregation and the characteristics of "gendered" occupations. The present research seeks to understand how gender essentialism affects women's preference for performing emotional labor and the consequences of this outside of the general restraints of working in a feminized occupation. This study focuses specifically on the experiences of women, as women are overrepresented in fields that require emotional labor as an essential job function (Hochschild, 1983). The funeral industry provides a unique context for the present research because of the historical numerical domination in the industry by men (BLS, 2010), despite the focus in the industry on stereotypically feminine traits related to emotional labor, such as the display of nurturance to clients (Bailey, 2010).

In order to gain an in-depth understanding of the meaning of emotional labor in the funeral industry, qualitative research methods were used in this research. Qualitative approaches often allow for a better exploration of the complexities of an environment (Marshall, 1985), and were selected to allow respondents to openly express their 
experiences within the funeral industry in their own words. In the present research, one of the main goals was to explore how women's perceptions of job duties that involved a caring type of emotional labor were affected by working in a numerically maledominated field. Qualitative methodologies are generally considered a valid path to understand how the context in which actions are carried out influence their meaning (Maxwell, 2005). Further, since very little research has focused on the concept of "transgendered" occupations, the responses from this research were largely unanticipated. Qualitative methods allow for the reinterpretation of data during the research (Maxwell, 2005), and this flexibility was necessary in order to understand emerging discoveries and the relationships between the established theories utilized in this study.

Initially, this research was not explicitly focused on the operation of emotional labor, but rather the experience of women working in a male-dominated industry that focused on customer care. The first pilot interview that was conducted was an unstructured in-depth interview that fit Kahn and Cannell's (1957, p. 149) model of interviewing described as "a conversation with a purpose". The pilot interview was coded, organized into broad categories and analyzed according to grounded techniques (Glaser and Strauss, 1967).

From the initial pilot, concepts related to emotional labor and essentialist beliefs affecting work performance and experience became clear. A semi-structured interview script was developed from the first pilot, and tested again with another participant. The results from the second pilot were analyzed using the broad categories of emotional labor and essentialism developed from the initial pilot. Minor edits, such as the order and phrasing of questions, were made to the semi-structured interview script before moving 
into actual data collection. Neither of the pilot interviews with female funeral directors were included in the results of this research.

\section{The Sample}

In order to reach female funeral directors for participation in this study, several contacts were made to recruit respondents. First, two professional organizations specifically for female funeral professionals were initially contacted. These two groups emailed members the research solicitation, and included the information about the study in their monthly newsletter. From these two organizations, a total of four women replied, however only two completed the full interview.

A second solicitation was made to a larger funeral directing group that included both male and female members. This group was primarily an online social forum for funeral directors and did not have any formal professional affiliations. The group sends a daily forum email to members, and the research solicitation ran every day for one week. From this recruitment effort, twelve women replied, and seven completed the full interview.

At the conclusion of each in depth interview, participants were asked to refer anyone they knew who may also be interested in the research project. An additional four female funeral directors were recruited by word-of-mouth referrals.

A total of thirteen female funeral directors were recruited for interviews.

Participants were recruited from ten different states, as well as two participants that were working internationally at the time of the interview. Amber* was employed in Canada, but had lived in the United States previously and was familiar with the U.S. funeral 
industry. Likewise, Stephanie was in Europe at the time of the interview, but was licensed in both the E.U. and the U.S. Due to the fact that the sample recruited was geographically diverse, of the thirteen total interviews, eleven were completed by phone or online communication. Only two interviews were conducted in person. The interviews generally lasted about an hour. The shortest recorded interview lasted fortyfive minutes, and the longest slightly over an hour and a half. All of the interviews were recorded for later transcription and coding. Stephanie, the European respondent, requested the questionnaire by email and wrote answers to the main interview questions in a Word document. Her responses were followed by additional questions and points of clarification. There were a total of five email exchanges for this interview.

Of the thirteen women who participated, two identified themselves as Black, one as Hispanic, and one as Asian. The others described themselves as white. There was a great deal of variation in the ages of respondents. The average age was 42 , with a range of 25 to 61 . One respondent, Faith, declined to report her age. Because of the qualifications to become a funeral director, all of the women had obtained at least an associate's degree, and six women had completed a bachelor's degree. All of the women had at least two years of experience in the funeral industry at the time of the interview.

\footnotetext{
* This is a pseudonym given to protect the confidentiality of the respondent. All names stated hereafter can be assumed to be pseudonyms.
} 


\section{Data Analysis}

All of the interviews were digitally recorded and the responses from participants were transcribed into Word computer documents. After an initial read of all the transcriptions, the first phase of analysis was data reduction. In this phase, statements or quotations from respondents were edited into manageable sections of data with the intent to draw out consistent themes (Marshall and Rossman, 1989).

Once the raw data was cut down into useable sections, the process of category generation began. The present research utilized an inductive approach to category generation. Specifically, analyst-constructed typologies (Patton, 1980) using half of the recorded interviews were used to organize the data. In this approach, the researcher generated categories based on the literature and judgments about the variations that occurred in responses (Patton, 1980).

Once half of the interviews were organized into the analyst-constructed typologies, the emergent themes were tested using the other half of the interviews. The second half of the interviews were searched for negative cases or themes that were not covered by the original typologies. This approach helped to evaluate the analytical categories in terms of their credibility and usefulness in explaining the data (Marshall and Rossman, (1989).

The main themes that emerged after all of the interviews had been categorized were: the performance of emotional labor as an essential job function, the experiences of gender-based discrimination on the job, and beliefs in essentialism as they related to 
performing emotional labor. These themes were then considered for internal convergence and external divergence (Guba, 1978), that is the themes were judged to be salient, yet distinct from one another. 


\section{CHAPTER IV}

\section{RESULTS}

\section{Emotional Labor as an Essential Job Function}

According to Hochschild (1983), emotional labor is the act of expressing certain emotions in order to create feelings in others. When asked to describe their basic work duties, the respondents unanimously described acts to show support for families of the deceased in order to calm them through the grieving process. For example Sarah, a 57year-old who had been working as a funeral director for nine years, stated "I think it's my job to have an awareness and a knowledge to help people through a difficult time when they're not thinking clearly." Likewise, Rachel, a 45-year-old with 17 years of experience, described her work as a funeral director as:

"Caring for the family, it's a very bad time. I want to be the solution, not part of the problem. Use the correct tone, the correct amount of empathy... Someone responsible for making sure the family gets what they need at the time. It's a painful professional service, but it's my responsibility to get what is contractually obligated. As well as thehuman side, being there for them emotionally, the warmth, the care, the compassion, and of course, the professionalism."

Similarly, Vera, a 51-year-old from Illinois, said: 
"My job, my first five minutes with the families, is just to make them feel as comfortable as possible and make them trust me... I put myself at their level... if they show me a picture I always say 'oh my god, I used to have a picture just like that' or 'I used to wear my hair like that'. Anything that I can say to put me at their level."

The terms used for describing emotional labor in the funeral industry, such as "caring" or "compassion", are also stereotypically feminine traits, which Hochschild (1983) believed to be one of the main contributing factors to negative consequences of emotional labor for women. Jennifer, a 58-year-old who owned her own funeral home, who described her work in funeral directing as being "nurturing", elaborated with her comment "I think nurturing is being willing to cry with people, hugs, if they need it, and trying to do things that they really feel strongly about." Nancy, who was on leave from her work to take care of her young child, said "I wasn't just there to push the funeral through. I needed to be there for the family and meet all of their needs."

The task of controlling one's emotional displays in order to support families was not always described as effortless or uncomplicated. Just as Hochschild (1983) noted that the flight attendants in her study were often required to tolerate angry, or even verbally abusive, passengers in order to maintain their emotional display, the respondents described a similar level of control when dealing with particularly difficult families. Melanie, a 25-year-old who entered the funeral industry immediately after high school, recognized that the same care needed to be given to families regardless of their treatment of her with her statement that her work role was: 
"Really just being there... showing that you're there for the families and I think that came through more so than trying to say something cliché, like 'sorry for your loss'. For somebody that lost somebody it's more than a loss... somebody's life is worth more than just a loss... basically you're there for the family. You're going to do the last time that they're going to see their loved one in most cases. You're the one they chose to do the funeral with, and you're going to be the one to make a last picture of the deceased... a lot of people will remember little things that happen, whether they are negative or positive. You just really have to be there for the people, whether they have a negative attitude, or they're angry, or whatever their emotional stage is, you just have to be there for them... I think my role will be someone who just likes to go above and beyond... I still take it very seriously because I'm going to have to do my $100 \%$ best and give that loved one the best care that I can. I feel like my role as a caretaker is to just be there no matter what. No matter is somebody is yelling at me, or angry, because a lot of times you will meet families that are not in the happiest period, just to say even though they're acting this way, I'm still going to give them $100 \%$ because that's what they deserve."

Some respondents indicated that they had the potential to deflect negative feelings from customers by performing emotional labor. This was often described as going beyond what would be needed for the "average" family and preemptively taking on a more exaggerated caregiving role. For example, Amber stated that she treats widows with particular caution in her comment, "I sometimes find the widows, not so much the men, it's the ladies, that need that little bit of extra. Even if it's as simple as offering an arm for her to hold onto and walk along his casket." Becky, a 61-year-old who co-owned a funeral home with her husband, described this as being particularly protective of certain people with her statement "first of all, we're very protective of the families that we 
serve... If somebody asks for something, I will do everything in my power to make that happen. And as far as babies... very, very careful. We take very good care of them."

Despite the emphasis that all of the respondents placed on showing support to customers, it is important to note that the emotional displays of respondents were not limited to simply showing caring. Many respondents describe having to vary their emotions in order to support the families they served, however, they still required "being nice" as an essential job function. For instance, Faith, who had 19 years of funeral directing experience, described the need in funeral directing to display a lighter side in order to lift the moods of customers. She said "In this business, it's not all total gloom and doom. You've got to have some levity somewhere, there's got to be some comic relief, if you will. From the point of even sitting at a conference table with families because it's like, they're remembering all these wonderful things about mom or dad and the funny things they did. But, it's like they're afraid to let themselves laugh, like that's disrespectful. So you have to learn where to insert a little bit of comedy relief for them... But you've got to because you are kinda for that two hour window and the next three days, the liaison that's gonna be there for whatever it is that's needed and to talk to and to listen. It's about listening as much as it is imparting education info and things like that to the family." Similarly, Amber, who was working in Canada at the time of the interview, said "I'm a bubbly person, I'm positive, I smile a lot, I love laughing, and if I can bring that into my job and how I'm interacting with families, then I will. And there are many times that I have. A lot of people think funeral directors, and I've actually gotten this comment back from a few families, 'I always have this idea that funeral directors are very straight-laced, they're very somber, and you're the complete opposite of that and it's a 
good thing. You made us laugh, you made us smile, you definitely brightened the situation a little bit. Brought the joy out of celebrating our loved one's life as opposed to mourning their loss."”

\section{Preference for Service Work}

Research has noted that women, more often than men, tend to be employed in jobs that require high amounts of emotional labor (Glomb et al., 2004). While Hochschild (1983) hypothezied that this had negative psychological consequences for women, some respondents expressed that the desire to care for people was a strong motivation for becoming a funeral director. Here, emotional labor moves from a simple job function to an expressed preference for some respondents. When asked why she decided to become a funeral director, Melanie responded:

"It's really been something that I always wanted to do since I was little. I like to help people, and I'm also very interested in the embalming aspect of it as well. Just those together, that's what really put me into the business... I feel like it's a really fulfilling business as far as what you do for people and how we are an assistance to families. And so that is what your goal is, what it's your desire to do. The gratification that you receive in doing so, you can't even... express that." Similarly, Jennifer explained "It wasn't a conscious decision. It wasn't something that I said, oh gee, I think I'm going to be a funeral director in the future. I started working as clerical staff in another mortuary and I really, really enjoyed working with the families. So I went out and got my funeral director's license." For Amber, her motivations for entering the industry were explicitly to fulfill a caregiving function. She said "It's 
something that my mom suggested when I was in university. She lumped it together with social worker or counselor. She was like 'you could do something like that'. I didn't really think much about it and then the next year after my second program change, I really looked into it and decided that hey, this might be for me."

Interestingly, many of the respondents had prior work experience in other service fields that required emotional labor. This would seem consistent with previous findings that state women are crowded into positions that focus on customer interaction (i.e. Fitzsimmons, 2002). Further, many respondents recognized the connection between other types of service work and employment as a funeral director. For instance, Sarah, who had previously worked as a child advocate in juvenile court and as a pastor, stated:

"I think my having been a pastor and a hospice chaplain very much informs the way I am a funeral director. I think I have a different kind of sensitivity to families and a little bit of a more awareness of the process, so I can help them in their new needs, as well as their other needs. I understand the grief and bereavement process after that."

While the work in hospice care may be more clearly related to funeral directing, other respondents related other, more ambiguously related, occupations. Vera had also held several jobs that required extended customer interaction, such as car sales, bartending, and bridal consulting. She said "I came to the conclusion that the bottom line was what makes people successful is not so much how much money you make, but it's more how you serve people...I always tried to pick jobs that I can serve people ... I've always liked jobs that you serve people and talk to the public." Amber, who used to work in a grocery store, explained "I had to deal with people. I had to learn very quickly how to deal with disgruntled people and those skills, and even though it is a different situation, 
they definitely helped me keep on my toes and keep my head when I'm dealing with a difficult family." Debbie, a 26-year-old who used to work in the food service industry, said the commonality between both jobs was that "You have to have a good personality. If you're not a people person then funeral directing is definitely not for you." One respondent, Stephanie, who was previously employed as a wedding photographer, wrote that she learned about:

"Dealing with all the types of people (religion, social level...). Dealing with all the types of characters (funny, severe, aggressive...). Dealing with problems inside a family (fights between family and family-in-law, choice of life of some members of the family...). Knowing how to act in case of emergency (sudden and unexpected discomfort of a relative, something forgotten, broken or missing...) Knowing that a wedding ceremony as a funeral ceremony is unique for the people involved in it."

\section{Experiences of Gender-Based Job Discrimination}

Despite the fact that the respondents described the emotional labor in funeral directing in stereotypically feminine terms, funeral directing remains a numerically male dominated profession (BLS, 2010), fitting the description of a "transgendered" occupation outlined by Britton (2000). The female respondents operated under an explicit awareness that they were in the minority. All of the respondents had at least one instance where they felt they had experienced gender discrimination on the job, or were treated unequally in some fashion. Sarah, who had worked at her place of employment for nine years, said "I think that the ownership is more inclined to think of me still, even after all these years, as a secretary than as an equal funeral director." 
Sometimes the discrimination respondents described was outright, especially in hiring. Although Melanie said that she did not feel as though she had experienced this issue herself, she stated "People I know have run into some problems with people who don't hire women funeral directors, and they try to go out for a job with somebody that was hiring, but they're clearly not interested in a female applicant." Similarly, Rachel said "I think the problem comes when you actually step out into reality because it's still a male dominated and male oriented field. I don't have any suggestions for that, unless a whole generation retires or dies." Vera had personally experienced problems in the funeral industry and attributed them to men not wanting to hire women. She explained "The problem is, is that it's a very male dominated industry. .. It's hard for women to get jobs ... I couldn't find an apprenticeship," and added "The males are never going to trust you because it's very male dominated work... men have this thing that they have to take care of females." In the most extreme case, Lisa, a 35-year-old from Florida, was currently unemployed and had not been able to find work in the funeral industry for some time. She directly attributed this to gender discrimination and has begun to look for work in other occupations. She explained:

"I think it's you still have these old timer men funeral directors who if the ones that own, or they're in upper management, they tend to be sexist. l've worked for several men like that, they are sexist. When I tell people what I do, I've had comments, they well, why do you do that, you're a woman, things like that. I mean, it is a good job, but I just don't think it's worth it."

Similarly, Debbie said:

"A lot of funeral homes will flat out tell you that, even though I think this is illegal too, that they're not going to hire you because you're a woman. I've had 
several managers tell me that. And the only funeral homes I've worked at have already had women in there, and I think they kind of paved the way for me to make it easier. But, I think I would have a difficult time getting into another funeral home if another woman hasn't previously worked there."

Many women reported having to change their behavior in order to overcome what they felt was gender-based discrimination. This was most often described as having to be very careful not to make mistakes in the fear it would be attributed to the respondent's gender. For example, Lisa said:

"I just try and take my time that I do everything right. I don't want to make a mistake to have somebody say something, and I try and do the work without asking for help. I try to do most of the stuff without asking for help because I don't want them to say 'well, if you were a man, you wouldn't need the help'. So I just try to do things more on my own without asking for help... I think it makes me work harder as a woman because I'm always being compared to a man and doing a man's job so... I don't like asking for help, so I want to work harder so I'm not compared to a man."

Stephanie described her adjustments in terms of having to control her emotional displays. In effect, this was a different sort of emotional labor in itself. She wrote:

"From time to time working in different shops of the firm (flowers, funeral items...), everyone was 'waiting for me to pounce'. I've never weakened in front of a body, even a mutilated one or discovered one several weeks after death. I've never cried in front of a baby or child body (the worst cases in the business as you can imagine). I know that could happen tomorrow, there is no immunization and it's only human. But if that happened during my training, for these men it could be a proof that women are not good for this job." 
Other women had a more optimistic view of the gender balance in the industry. Faith, one of the more veteran respondents with 19 years of funeral directing experience, stated, "Anything that you do, especially when it's been in a men's industry, you initially feel like you have to do everything twice as good, to measure up... you just learn how to roll and you learn how to do what you need to do and you learn that men put their pants on one leg at a time just like I do, so it doesn't give them an edge." Amber reported taking pleasure in finding work in a predominately male industry with her comment "It's not a boy's club anymore. It's not just strictly for the men. Women are trying to make themselves more equal in this world and infiltrating an industry that traditionally was very male dominated. ... to me, if you're an extreme feminist it's one of the perfect ways to assert your feminist ideals because look, I made it in a boy's world."

\section{Masculinizing the Work of a Funeral Director}

While all of the respondents described the emotional labor demands in the funeral industry in stereotypically feminine terms, many respondents described aspects of the industry in more stereotypically masculine terms. Some respondents reported adopting what could be thought of as stereotypically male traits, such as assertiveness, in order to overcome gender discrimination in the funeral industry. Debbie stated that the reason her job experience was not affected by her gender was because of adopting more stereotypically male traits. She explained, "I'm very aggressive. I'm very independent. I'm not afraid to just jump in there and be the first person to try something, if nobody's done something before. I'm very motivated, and I take initiative, so that's why I've not had a problem. But I think if I was a little more quiet, I don't think they would ask me." Similarly, Amber said: 
"I am the kind of person where I go to the horse's mouth... if you don't have to involve management and the powers and what not, with a problem, then just deal with it on your own, really. So when a guy would start trying to shove me aside because they didn't think I could do it and whatnot, I would look at them, 'excuse me, what do you think you're doing?' 'You can't lift this.' 'Yes I can. If I needed your help, I would have asked for your help'.... It didn't take very long for people to stop trying to baby me in that respect. They realized very quickly that "you know what, she is very capable of doing things on her own, and if she needs help or if she has a question, she will ask."”

It should be noted that Debbie, who was 26, and Amber, who was 27, were two of the younger respondents in the sample, and their willingness to directly dispute stereotypes in a confrontational way could possibly be attributed to their age.

Although the respondents felt as though they did experience gender discrimination in the funeral industry, there were some respondents that felt as though women could not equal men under one circumstance. That is, many respondents described that there were aspects of funeral directing that could be physically demanding and felt as though men could possibly handle those aspects of the job more easily. This is consistent with previous studies on nursing, a numerically female dominated job that is widely considered to be feminized, found that men were accepted as nurses only on assignments that have a physically demanding component, such as constraining distraught patients on psych floors (Gray, 2010). In the funeral industry, the respondents limited their perceived weaknesses to removals, when the body of the deceased needs to be moved from the home or hospital to the funeral home. Joanne said, "I think you're at a disadvantage because the weight requirements, you're having to lift bodies. A lot of 
men don't want to hire you because you don't think you're going to be able to do it by yourself. I have to go pick up bodies by myself." Similarly, Becky said:

"The only problem I have seen is that there are times when being a women, maybe I don't have the strength that some of the men have. So to lift and stuff. Physical strength. But when you can't do something all by yourself, you ask. Whether I'm in a hospital and I need assistance, there are nurses there. Or if I'm at a home doing a removal, which we always try to have two people there, but in the event I have other people out on other removals, if there a hospice person. You just don't assume you can do it all yourself. And I'm always prepared for that. So even though I know what my physical limitations are, you get help. You just ask, it's fine. And not all men can do it either... just maybe they can do some a little bit better than I can."

A few women not only expressed that females were physically weaker than males, but seemed to exaggerate the strength difference. For instance, Vera commented "If a 300-pound person dies in their home, I can't pick them up by myself. I have to get somebody and take somebody with me. The funeral home only wants to pay one person... they're just going to get a male, because a male can lift heavy bodies and a female can't." This statement seems to be somewhat of an exaggeration, as there are probably relatively few males in reality who would be able to lift over 300 pounds. Only one respondent, Amber, challenged the idea that men are better suited for the physical tasks of funeral directing. She said, "At first, especially with my internship, a lot of the guys were like 'step back and we'll let the men do this', and I would look at them and be like bullshit. I am a lot stronger than what you think I am, I'm not this dainty little woman." 
In addition to feeling discrimination from male co-workers and management in the funeral industry, the respondents also indicated that customers are also generally surprised to be dealing with a female for funeral services. For example, Debbie stated:

"If I have a male coworker with me, people will go right past me to him. Even if he has more or less experience, it doesn't matter, they just completely ignore me. Just because I'm a woman, I think. Other than that, I think it's just a surprise factor because people aren't expecting a female and if a man happens to be with me while I'm speaking to people, like I said, often times they will speak to whoever the gentleman is instead of myself."

Some women reported having difficult experiences with customers because they were female. Lisa said:

"I had an experience one time where I had an older gentleman, his wife had passed away. I had come in the room... when I sat down and started talking, he was like, 'well where is the funeral director' and I said 'I am the funeral director', and he didn't believe me. And he didn't want to, he said, 'well, you're a women and you're young' and he didn't want to talk to me. But then once I continued on, he didn't want to talk to anybody but me afterwards. So sometimes you just have to get people's trust."

Becky had a similar story:

"On occasion you get a male, a very dominant male that doesn't want to be told what they need to do by a woman. When I say told what to do, there are certain things in our business, certain ways we have to do things. I cannot bury or do a cremation without a permit. Can't get a permit without a signed death certificate, cannot get a signed death certificate unless I have all the information. It's just the way it is... I had one particular man and he wanted me to do it a different way, and it would not happen. It can't... he was getting a little loud... I remember sitting there and I raised my voice... I remember him just trying to tell me how to do my job when he had no idea and it couldn't be done that way. And when I raised my 
voice and kind of leaned in to my desk to let him know that it is not the way it is going to happen. All of a sudden this man started to back down... in a way I'm laughing inside because wow, I just became a little more forceful and then he backed down... I explained it, he backed down."

Other respondents did not have as confrontational experiences with customers, but had to deflect stereotypes nonetheless. For instance, Rachel, a 45-year-old with 17 years of experience, said:

"People will say 'you don't look like a funeral director' and I will say 'well, what does a funeral director look like?' And then there's times where I'm getting in a hearse and a man will stop me and say, 'are you going to drive the hearse?' and I want to say, 'how do you think we're going to get there?' but I don't. I just say 'yes, I am'. It takes some getting used to."

A few respondents even reported people within the funeral industry assuming that other funeral directors were male. Stephanie wrote:

"In 1990, I was the manager of an agency in the large funeral group I was working for. One day, I had to attend a meeting and buttons with name and position were at the front desk. Mine was written 'Mr.' as all the others. I've shown the mistake to the woman receptionist whose answer was, 'Wear it. Everyone will see you're a woman'. I said 'In this crowd there are many people who don't know me... some of them could think I could be a drag queen. Find me a right button."”

\section{Notions of Gender Essentialism in the Performance of Emotional Labor}

Hochschild (1983) hypothesized that emotional labor has special consequences for women. In the literature, this has most commonly been investigated as a gender difference in the experience of burnout (see Wharton, 1993). Based on statements from 
the respondents, funeral directing, for them, seems to meet most of the conditions Hochschild outlined that would disproportionately affect women. The respondents indicated that "being nice" was an essential job function. Additionally, respondents indicated they felt were in a subordinated to men within their workplaces, and they were often subject to the scrutiny and demands of customers. In spite of this, very few women indicated they had any kind of dissatisfaction with the funeral industry. The only strong expression of dissatisfaction was from Lisa, who has stopped looking for employment in the funeral industry because of perceived sexism.

In fact, rather than express burnout or dissatisfaction, most respondents indicated that they were quite happy in their occupations as funeral directors. Melanie said "I feel like I'm doing something admirable. I'm very, very proud of what I do... I've had an impact on somebody and I did that I feel like my life is complete... knowing I'm able to show the families I care for them and care about whatever they are going through." Rachel, who was only working as a funeral director part-time at the time of the interview, said "It's my dream to get into funeral service full time". Likewise, Stephanie, who had been working in the industry for over 20 years, wrote "I'm deeply proud of my job and I hope to remain in the business till [sic] my retirement." This is consistent with the research on essentialism outlined by Charles and Grusky (2004) that found many women will express a preference for work based on a self-evaluation of their skills. Although Charles and Grusky (2004) added that essentialist beliefs may lead women to avoid maletyped employment, many of the respondents argued that because of the emotional labor demands of funeral directing, women were actually well-suited, or possibly better suited for the occupation. 
The essentialist beliefs expressed by respondents as they related to the emotional labor requirement of funeral directing can be categorized in two distinct fashions. Some women expressed that women have certain innate characteristics, such as being more caring. For example, Nancy rooted her opinions in the belief that women were more emotional than men with her statement, "The woman is naturally more compassionate for the families, maybe more empathetic because we are more emotional." This is, in effect, expressing a belief in essentialism itself. Other respondents disagreed with essentialist notions that women have an inborn nature to be more caring, but still expressed that this is a common sentiment in society that they capitalized on in their work. An example is Amber's statement, "I find with women people are more forthcoming ... I find people open up a lot more when it comes to feeling with a female in the industry. I don't know what it is." Here, while Amber did not say she felt there was a difference in the ways that men and women were able to care for people, she did note that others reacted to women funeral directors differently than males without a basis in individual characteristics.

\section{"Women are": The expression of a belief in gender essentialism}

Eight of the thirteen respondents made statements about the perceived nature of women being of value in funeral directing. These statements were the direct expression of essentialist beliefs held by the respondents that corresponded directly to job skills they believed were valued within the funeral industry. When asked about the requirement of funeral directing to display nurturing, Rachel replied, "I think it's an inborn skill. The motherly instinct. The patience, I think it's just how we look over, I think that even though women are business oriented, they still can make someone feel very comfortable and more at ease." Similarly, Lisa said "I think the whole wanting to help and the more 
nurturing, women tend to be more nurturing than men, ... I think you could just say that women do it because they're more nurturing and want to help the people." Becky shared this view and added that women "... have the sensitivity and the caring that goes... It's like an inborn instinct. We may know how to talk to people. I think we look at it beyond a sales approach and more as a caring, you're my friend, let me help you."

A few respondents actually argued that the nature of women did not only qualify them to be funeral directors, but extended this to mean that women were, on average, going to be better at performing the job function than men. The role of caretaker respondents' described adopting when interacting with female customers may be related to other research lines that indicate same-sex friendship may be more emotionally committed than friendships between members of opposite sexes (Johnson, Brady, McNair, Congdon, Niznik, and Anderson, 2007). Jennifer expressed this sentiment with her comment, "Some ladies that I have taken care of their husbands when they've died, and they still call me to say hi, see how I'm doing. And I still call them to see how they're doing... men just don't seem to do that... Women do that. They confide in each other even if you barely know them." When asked how she thought a man viewed the need to be nurturing within the funeral industry, Jennifer continued, "Shaking hands or something. I don't know, because most men are not what you would call nurturing... It's a very maternal thing. It's something a man will never feel." This comparison to males was also used to counter the idea that customers treat women differently. Some women were able to put a positive spin on the differential treatment by attempting to explain the "nature" of women. For instance, Faith said: 
"A lot of times I find families are a little more comfortable talking with a female than a male. So I think women have a lot to bring to this industry. We're very detail oriented. We're very fashion conscious. There's just little nuances and things that women put into this that men don't. Men just aren't geared for that."

Joanne expressed a similar sentiment with her comment "I think it's an instinct that women have over men... I think a man... is more of a leadership role.. let me lead you through this funeral process. Versus a woman being a more nurturing, let me help you through this process." Vera said "I think women make better funeral directors. I don't think it, I know it... They're more compassionate. They have more attention to detail and they're more focused."

People Think Women Are: The expression that society holds essentialist beliefs

In contrast to the respondents that made statements that indicated they themselves held essentialist beliefs about the nature of women, five of thirteen respondents said that, while they did not believe that women could automatically be assumed to have certain traits, customers may, and this still influences how emotional labor by women could be performed. Stephanie expressed this sentiment when she wrote, "I've noticed that some people share more intimate information with a woman funeral director than with a man one [sic]. Some seem more comfortable to explain a problem in the family, to ask a special request... I don't think it's a matter of gender. It's the way that the gender is seen in the collective unconscious." This perception of essentialist beliefs in customers in turn permitted the respondents to act in a way that was consistent with essentialist beliefs. For example, Sarah said: 
"Women are allowed to share emotion, so I don't have a problem crying with the families." When asked to expand on this response, she continued that beliefs about the nature of women "... allows me the opportunity, at least, to be more sensitive. I think men get short changed on that. I don't think they're allowed to be as emotional as women are allowed to be."

Melanie expressed the same ideas about the beliefs of customers, but remained unsure as to whether or not this actually changed the service they were going to receive. She explained, "I think a family might feel a woman funeral director would be more nurturing. The comments that I've heard before of 'oh, we're happy that a woman's here', they think they're going to get a little bit more caring, but it really just depends on the person."

A few respondents made statements that essentialism might not be biologically or innately based, but became real in its consequences from the ways that men and women are expected to act in society. Here, the essentialist beliefs were not representative of an innate biological difference between males and females, but rather the differences in socialization. For example, Amber noted that women did treat customers differently, but believed this was an extension of the way that males and females were treated as children. She said:

"I find women tend to have a softer approach when it comes to people. I think we're from a very young age we are taught to be softer and to be gentle and to you know, play nice and watch how you talk to people, where boys are very.. aggressive. Rough housing, play fighting, things like that, and they lose out on that opportunity to really develop those skills."

However, Amber also clarified that she did not think that this difference in socialization was absolute. She explained, "Women are supposed to be the caring, gentle nurturing 
ones and the men are supposed to be a little rough around the edges. Do I think that's correct all the time? No. I've met a lot of men who are very caring and nurturing and women who are little rough around the edges. But, in terms of the stereotype, yes, that's totally how it is." Similarly, Debbie noted that there was a skill difference between men and women when it came to preparing the deceased for funerals, but that this was a result of social differences rather than biological ones. She said, "I think that I excel far more at restorative work than the men in my business though. Restorative work concerns things like, for example, just simple things like cosmetics and hair or nails. It's because us girls we know how to do that kind of thing up front from practicing on ourselves for so long."

\section{Summary}

The respondents in this study unanimously described emotional labor as an essential job function. The desire to care for others, or perform service work more generally, was a motivation for many respondents to enter the funeral industry. Despite the value respondents placed on their emotional labor, they also felt that their gender placed them at a disadvantage with their male-counterparts in terms of obtaining work and upward mobility. Despite the internal business conflicts respondents felt as attributable to their gender, they believed that being a woman may help them in relationships with customers. This was described as the belief that women are naturally more sensitive and caring, or that customers would prefer to work with women funeral directors. 


\section{CHAPTER V}

\section{DISCUSSION}

This study focused on women who performed emotional labor in a maledominated occupation-- the funeral industry. Previous research on emotional labor has primarily situated itself in occupations that require both feminine-typed emotional labor and as being numerically female dominated. However, the ways that the work performed within an occupation are gender typed, and the demographic majority of that occupation, do not always clearly align (Britton, 2000). It is important to look outside of femaledominated occupations in order to fully understand how emotional labor affects women.

All of the women in this study described the emotional labor they performed in the funeral industry in stereotypically feminine terms, such as displaying caring or nurturance to customers. In contrast to previous research on women in transgendered occupations that found women denied emotion work in order to achieve parity with men in the field (Irvine and Vermilya, 2010), most of the women in this study did report adopting stereotypically male traits. Despite the high value respondents placed on their emotional labor, the women in this sample unanimously had at least one instance where they felt they were discriminated against on the basis of their gender alone in the 
funeral industry. This seems to highlight the relative devaluation of women's work (Sweet and Meiksins, 2008), even in a field that largely excludes women.

Despite the descriptions women offered of having a lower status in the funeral industry relative to men, as well as reporting having a high demand for emotional labor as an essential job function, most of the respondents in this study did not report having any sort of dissatisfaction with their job. This seemingly contradicts Hochschild's (1983) assertion that emotional labor would lead to higher rates of burnout for women. In fact, many of the respondents argued that their gender had a positive influence on their work that made their relations with customers more fluid, or in some instances, better. This point was stressed by evoking notions of gender essentialism.

Most of the respondents expressed that they held a belief in gender essentialism. This was most commonly present in statements that indicated they believed that women are inherently more caring or nurturing, and therefore the demand of emotional labor is just the expression of an innate characteristic of being female. While Hochschild (1983) stated that women are believed by employers to manage emotions better than men, statements such as these indicate that it is possible that many women hold this belief themselves. Here, gender essentialism may have a dual influence-- women may be more likely to be hired in positions that require emotion management, but they also may prefer to work in such positions based on internalized beliefs about their gender. This supports literature that suggests essentialism influences women to select career paths that involve the expression of stereotypically feminine traits (Charles and Grusky, 2004). However, in contrast to the assertion that women were usually not aware of how essentialism affected their work preference (see Xie and Shauman, 2003), the respondents in this 
study were able to directly tie their job performance to what they believed were innate characteristics resulting from their biological sex.

Other respondents indicated that while they did not believe one could assume people had certain characteristics on the basis of gender (such as women being more caring), other people did have essentialist views of gender that affected their job performance nonetheless. This was usually expressed in statements that indicated that the women in this sample felt that customers treated them differently by being more open about their emotions in the belief that women would be more receptive to those feelings. This response was interesting because the respondents operated off an implicit assumption about what others thought about women, and was an indirect way of using gender essentialism as an explanation for their feelings about their job experience. Past research has suggested that exposure to essentialist thinking, even if the individual does not personally accept it, may still influence behavior (Morton et al., 2009). This explanation seems plausible in the present research, as many respondents had previous employment in other feminized service industries, but cannot be directly examined in the results of this research. Although respondents were asked about previous work history, exposure to essentialist thinking in those jobs was not questioned sufficiently to draw firm conclusions.

In explanations of how the respondents felt as though their gender influenced both their work performance and work experience, they evoked stereotypes about the nature of women. Irvine and Vermilya (2010, p. 74) referred to this as "women stereotyping other women". Women working in male dominated fields are often thought to face unfair treatment because of violating the gender norms of the occupation (Dingfelder, 2004). 
However, in this study, while the women did describe unfair treatment, such as lower wages in comparison to men, they combatted this by evoking gender stereotypes that allowed them to argue they were naturally more suited to perform emotional labor. This could be seen as evoking gender stereotypes to combat other gender stereotypes, and suggests that essentialism can still influence women's work preference even in maledominated fields. Future research concerning the effects of emotional labor for women should begin to incorporate beliefs about gender essentialism as a possible mediating variable between emotional labor and the effects of burnout.

The present research has several important limitations. First, the generalizability of these findings is not known. Only thirteen female respondents participated in the research and were recruited by volunteering their participation in the study. This was not a randomly selected sample. A larger, randomly selected sample of women funeral directors would need to be interviewed in order to have a better understanding of how essentialist beliefs affect the preference for work in the funeral industry, as a job that requires high amounts of emotional labor. It would be interesting to compare the findings of this research to a sample of male funeral directors. It is possible that males in the industry define their work roles in reference to the performance of emotional labor in a different fashion. Although the present research focused on females working in a numerically male-dominated occupation-- the funeral industry-- no comparison between male and female funeral directors can be made from the results of this study. This research also focused on a single instance of women working in a male-dominated occupation. It is possible that other jobs also require high amounts of emotional labor 
while still being numerically male dominated. For instance, clergy work would provide a similar research context that may broaden the scope of the present research.

The lack of respondents describing burnout, as well as the high number of respondents reporting that they were very satisfied with their jobs, may be a result of response bias. The social desirability bias is generally defined as answering questions as a "good" person rather than express what is actually felt (Vogt, 1993). It is possible that respondents reported being satisfied with their job due to not wanting to be perceived negatively, rather than because they actually enjoyed their job.

It is also impossible to speak to the direction of causality. All of the women in the present study expressed some type of essentialist notion, whether statements that they themselves believed in gender essentialism or simply the belief that the larger society did. However, it is not known whether respondents that already held some sort of belief in gender essentialism self-selected into an occupation that expressed that belief, or if repeated exposure to the work environment that demanded "being nice" as a job function caused an internalization of essentialist beliefs.

This research may have important implications for how stereotypes, and perceptions of stereotypes, influence occupation choice. The finding of the present study that outside beliefs in essentialism affected women's work preferences may have relevance for other groups typically excluded from certain occupational fields. For example, research on children from lower-class backgrounds has shown that socioeconomic status affects various life outcomes including occupational choice and educational attainment (see Oldfield, 2007). It is possible that stereotypes about the 
working class, along with numerous structural barriers, can influence the career and educational choices of lower-class children.

It would also be interesting to examine customer's perceptions of men and women performing the caring type of emotional labor as they relate to the quality of service received. While the women in this study reported being able to better handle the emotions of customers based on the perceived essentialist beliefs of those clients, it is not known if this is actually true. This study concerned beliefs about gender. Whether or not there are actual differences in the emotionality of men and women are not examined or addressed. Despite the popular belief that women are more emotionally sensitive than men, recent research suggests that emotional sensitivity is not solely a function of gender (Boise and Johnson, 2007; Mikkelson, Farinelli, and La Valley, 2006).

The present research questioned the possibility that the negative effects of emotional labor for women are largely embedded in the consequences of working in a feminized occupation. This study of women's emotional labor in a setting that was not numerically dominated by women found little evidence of burnout. This appeared to be largely explained by participants evoking essentialism, or the essentialism of others, as a means of tying their identity to their work roles. As suggested by Ashforth and Humphrey (1993), social norms may influence, or reinforce, career paths of individuals in a variety of ways. As diversity in American workplaces continues to increase (Sweet and Meiksins, 2008) it is important to examine how stereotypes not only act as barriers for certain groups, but also influence people's preference for different occupations. 


\section{REFERENCES}

Alksins, C., Desmarais, D., \& Curtis, J. (2008). Workforce segregation and the gender wage gap: Is "women's work" valued as highly as "men's"? Journal of Applied Social Psychology, 38 (6), 1416-1441.

Allison, S.T, Beggan, J.K., Clements, C. (2004). Derogatory Stereotypic Beliefs and Evaluations of Male Nurses. Equal Opportunities International, 23 (3), 162-178.

Ashforth, B.E. \& Humphrey, R.H. (1993). Emotional Labor in Service Roles: The Influence of Identity. The Academy of Management Review, 18 (1), 88-115.

Bailey, T. (2010). When Commerce Meets Care: Emotion management in UK funeral directing. Mortality, 15 (3), 205-221.

Banks, M. \& Milestone, K. Individualization, gender, and culture work. Gender, Work, and Organization, 18 (1), 73-89.

Bessen-Cassino, Y. (2008). The cost of being a girl: Gender earning differentials in the early labor markets. NWSA Journal, 20 (1), 146-160.

Bhave, D.P. \& Glomb, T.M. (2009). Emotional labour demands, wages and gender: A within-person, between jobs study. Journal of Occupational and Organizational Psychology, 82, 683-707. 
Bloise, S. \& Johnson, M. (2007). Memory for emotional and neutral information: Gender and individual differences in emotional sensitivity. Memory, 15 (2), 192-204.

Britton, D.M. (1999). Cat fights and gang fights: Preference for work in a maledominated organization. The Sociological Quarterly, 40 (3), 455-47

Britton, D.M. (2000). The Epistemology of the Gendered Organization. Gender and Society, 14 (3), 418-484.

Cathles, A., Harrington, D.E., Krynski, K. (2010). The Gender Gap in Funeral Directors: Burying women with ready-to-embalm laws? British Journal of Industrial Relations, $48(4), 688-705$.

Charles, M. \& Grusky, D.B. (2004). Occupational Ghettos. Stanford University Press: Stanford, CA.

Dingfelder, S. (2004). Women who succeed in male dominated career are often seen negatively. Monitor on Psychology, 35 (7), 12.

Erickson, K. (2004). To Invest or Detach? Coping Strategies and Workplace Culture in Service Work. Symbolic Interaction, 27 (4), 549-572.

Erickson, R.J. \& Ritter, C. (2001). Emotional Labor, Burnout, and Inauthenticity: Does Gender Matter?. Social Psychology Quarterly, 64 (2), 146-163.

Erickson, R.J \& Wharton, A.S. (1995). The Importance of Authenticity for Self and Society. Symbolic Interaction, 18, 121-44. 
Fiske, S.T. (1998). Stereotyping, prejudice and discrimination. In Handbook of Social Psychology by Gilbert T., Fiske, S.T. and Lindzey, G. p 357-411. New York: McGraw Hill.

Fitzsimmmons, S. (2002). Gender as a Verb. London: Ashgate.

Franzway, S. (2000). Women Working in a Greedy Institution: Commitment and Emotional Labour in the Union Movement. Gender, Work and Organization, 7 (4), 258-268.

Fromme, E.K., Drach, L.L, Tolle, S.W., Ebert, P., Miller, P., Perrin, N., \& Tilden, V.P. (2005). Men as Caregivers at the End of Life. Journal of Palliative Medicine, 8 $(6), 1167-\ldots$

Glaser, B. \& Strauss, A. (1967). The Discovery of Grounded Theory: Strategies for Qualitative Research. Piscataway, NJ: Rutgers.

Glomb, T., Kammeyer-Mueller, J.D. \& Rotundo, M. (2004). Emotional Labor Demands and Compensating Wage Differentials. Journal of Applied Psychology, 89 (4), 700-714.

Gray, B. (2010). Emotional labour, gender and professional stereotypes of emotional and physical contact, and personal perspectives on the emotional labour of nursing. Journal of Gender Studies, 19 (4), 349-360.

Guba, E.G. (1978). Toward a Methodology of Naturalistic Inquiry in Educational Evaluation. Los Angeles: UCLA. 
Guerrier, Y. \& Adib, A. (2004). Gendered Identities in the Work of Overseas Tour Reps. Gender, Work and Organization, 11 (3), 334-350.

Hochschild, A. (1983). The Managed Heart: Commercialization of Human Feeling. Berkeley: University of California Press.

Howarth, G. (1996). Last Rites: The work of the modern funeral director. Amityville, NY: Baywood.

Irvine, L. \& Vermilya, J.R. (2010). Gender Work in a Feminized Profession: The Case of Veterinary Medicine. Gender and Society, 24 (1), 56-82.

Johnson, H., Brady, E., McNair, R., Congdon, D., Niznik, J., \& Anderson, S. (2007). Identity as a moderator of gender differences in the emotional closeness of emerging adults' same- and cross-sex friendships. Adolescence, 42 (165), 1-24.

Kahn, R. \& Cannell, C. (1957). The Dynamics of Interviewing. New York: Wiley.

Kennelly, I. (2006). Secretarial work, nurturing, and the ethic of service. NWSA Journal, $18,170-192$.

Levanon, A., England, P., \& Allison, P. (2008). Occupational feminization and pay: Assessing causal dynamics using 1950-2000 census data. Social Forces, 88 (2), $865-891$

Mann, S. (1999). Emotion at Work: To what extent are we expressing, suppressing, or faking it? European Journal of Work and Organizational Psychology, 8, 347-369. 
Marshall, C. (1985). Appropriate criteria of trustworthiness and goodness for qualitative research on education organizations. Quality and Quantity, 19, 353-373.

Marshall, C. \& Rossman, G.B. (1989). Designing Qualitative Research. Newbury Park, CA: Sage.

Maume, D. J. (1999). Glass Ceiling and Glass Escalators: Occupational Sex Segregation and Race and Sex Differences in Managerial Promotions. Work and Occupations, $26(4), 483-509$

Maxwell, J.A. (2005). Qualitative Research Design: An interactive approach. Thousand Oaks, CA: Sage.

Mikkelson, A., Farinelli, L., \& La Valley, A. (2006). The influences of brain dominance and biological sex on emotional sensitivity, expressivity, and control. Communication Quarterly, 54 (4), 427-446.

Miller, K. I. \& Koesten, J. (2008). Financial feeling: An investigation of emotion and communication in the workplace. Journal of Applied Communication Research, $36(1), 8-32$.

Morton, T.A., Postmes, T., Haslam, S.A., \& Hornsey, M.J. (2009). Theorizing gender in the face of social change: Is there anything essential about essentialism? Journal of Personality and Social Psychology, 96 (3), 653-664.

Nickson, D. \& Korcyznski, M. (2009). Editorial: Aesthetic Labour, Emotional Labour and Masculinity. Gender, Work and Organization, 16 (3), 291-299. 
Nixon, D. (2009). 'I Can't Put a Smiley Face On': Working-Class Masculinity, Emotional Labour and Service Work in the 'New Economy'. Gender Work and Organization, $16(3), 300-322$.

Noor, N. \& Zainuddin, M. (2011). Emotional labor and burnout among female teachers: Work-family conflict as a mediator. Asian Journal of Social Psychology, 14 (4), 283-293.

Parsons, B. (2003). Yesterday, Today, and Tomorrow: The lifecycle of the UK funeral industry. Mortality, 4, 127-145.

Patton, M.Q. (1980). Qualitative Evaluation Methods. Beverly Hills, CA: Sage.

Oldfield, K. (2007). Expanding economic democracy in American higher education: A two-step approach to hiring more teachers from poverty- and working- class backgrounds. Journal of Higher Education Policy and Management, 29 (2), 217 230.

Reskin, B.F. (2000). The proximate causes of employment discrimination. Contemporary Sociology, 29, 319-328.

Reskin, B.F. \& Roos, P.A. (1990). Job Queues, Gender Queues: Explaining Women's Inroads into Male Occupations. Philadelphia, PA: Temple University Press.

Smith, T. W. (1999). The emerging $21^{\text {st }}$ Century American Family . GSS Social Change Report No. 42, National Opinion Research Center, Chicago, IL.

Sweet, S. and Meiksins, P. (2008). Changing Contours of Work: Jobs and Opportunities in the New Economy. Thousand Oaks, CA: Pine Forge Press. 
United States Bureau of Labor Statistics (2010). Occupational Outlook Handbook, 20102011 Edition.

United States Department of Labor. (1951). Occupational Outlook Handbook, Bulletin No. 998 .

Vogt, W. (1993). Dictionary of Statistics and Methodology. Newbury Park, CA: Sage.

Wharton, A. (1993). The Affective Consequences of Service Work: Managing Emotions on the Job. Work and Occupations, 20 (2), 205-232.

Wong, E. (2000). Funeral Business' New Look; as career prospects expand, work force becomes diverse. New York Times, November $10^{\text {th }}$.

Xie, Y. \& Shauman, K.A. (2003). Women in Science: Career Process and Outcomes. Cambridge, MA: Harvard University Press. 
APPENDIX A

TABLE OF RESPONDENTS

\begin{tabular}{|l|l|l|l|l|l|l|}
\hline NAME & AGE & $\begin{array}{l}\text { RACE/ } \\
\text { ETHNICITY }\end{array}$ & $\begin{array}{l}\text { YEARS OF } \\
\text { EXPERIENCE }\end{array}$ & DEGREE & $\begin{array}{l}\text { MARITAL } \\
\text { STATUS }\end{array}$ & $\begin{array}{l}\text { LISCENSE } \\
\text { TO } \\
\text { EMBALM }\end{array}$ \\
\hline Sarah & 57 & White & 9 & B.A. & Partnered & \\
\hline Melanie & 25 & Black & 5 & B.A. & Single & Yes \\
\hline Jennifer & 58 & White & 9 & B.A. & Married & \\
\hline Rachel & 45 & Black & 17 & A.A. & Divorced & Yes \\
\hline Becky & 61 & White & 20 & A.A. & Married & \\
\hline Lisa & 35 & White & 10 & A.A. & Single & Yes \\
\hline Faith & Declined & White & 19 & A.A. & Divorced & \\
\hline Stephanie & 48 & White & 27 & B.A. & Widowed & \\
\hline Debbie & 26 & Asian & 3 & A.A. & Single & Yes \\
\hline Amber & 27 & White & 2 & B.A. & Married & Yes \\
\hline Vera & 51 & Hispanic & 8 & A.A. & Divorced & Yes \\
\hline Joanne & 31 & White & 10 & B.A. & Married & Yes \\
\hline Nancy & 39 & White & 7 & A.A. & Married & Yes \\
\hline
\end{tabular}


APPENDIX B

INTERVIEW PROTOCOL

Section one: Becoming a funeral director

How long have you been a funeral director?

Are you dual-licensed?

Why did you decide to become a funeral director?

Were there any religious influences? Cultural values? Social values?

Any important life experiences that shaped your decision to become a director? Any important experiences with death?

Did you hold any jobs prior to becoming a funeral director?

Do you see any connection between previous work and work as a funeral director?

How did past employment help you? Has it hurt you in any ways?

What training did you receive to become a funeral director?

In terms if your training how do you think being a women affected that?

Did you complete an apprenticeship or go to college?

Was your overall training experience positive or negative? Why?

What was good about this training? What was bad?

What changes could be made to ensure gender-equality in the program?

What could be changed to attract more women to the funeral/mortuary sciences?

Would you encourage other women to become funeral directors?

Why or why not?

Section two: working as a women funeral director

How would you describe your basic work duties as a funeral director 
What are some business elements?

What are some caretaker elements?

Which role is more important and why?

How do you define "caretaker"? How do you define your role as a caretaker?

How important is this in the industry?

How do you think the elements of business and caretaking interfere with each other?

Can they help each other?

How do you think being a women influences how you do you basic work as a funeral director?

How does it affect business elements of your job?

How does it affect caretaker elements?

What skills/attributes are the most important being a funeral director?

Which do you have the most of/least of?

In general, do men or women have most of these skills?

What are the gender-consistent skills of your job duties? What are gender inconsistent skills?

Section three: Being a women funeral director in society at large

How do you view yourself in society at large as a funeral director?

How are women funeral directors treated by society?

How is your work treated by your friends and family?

What is your relationship with the business? What is other women's?

How are women treated by customers? Are they treated differently than men?

Section four: experiences with sexism and direct comparison to men

How has being a women effected your job experience?

Had it been positively or negatively?

What techniques do you use to overcome any negative experiences?

How has being a women affected your job performance?

What do you do to overcome any inadequacies?

Specifically, do you feel that you have experienced gender-based discrimination or sexism in the funeral industry? 
Define nurturing.

How would a man define nurturing?

How important is being nurturing as a funeral director?

Do you believe, on average, women in the industry are more nurturing than men?

Do you feel that men can be as good of caretakers as women can?

Why?

How would a man define caretaker?

How would they feel about being assigned this role?

Do you think overall men or women are better suited to be funeral directors? Why?

Do you feel that your general experiences within the funeral industry would be different if you were a man?

Anything else you would like to add?

Demographic

How old are you?

How would you describe your race or ethnicity?

What is your marital status?

How traditional would you consider yourself on a scale of 1 to 5 , if 1 is not traditional and 5 is extremely traditional?

To what is extent to do you have a feminist (or womanist) identity on a scale of 1 to 5 , if one is not feminist and 5 is extremely feminist? 


\title{
CURRICULUM VITAE
}

\author{
Allison-Scott Pruitt
}

Email: asprui01@Louisville.edu

Phone: (502) 558-7402

\section{EDUCATION}

M.A. Sociology, University of Louisville

4.0 GPA

Thesis: Emotional Labor in Gendered Occupations

Advisors: James Beggan \& Cindy Negrey

B.S. Sociology, University of Louisville, 2010

Minor: Communication

\section{PROFESSIONAL EXPERIENCE}

Fall 2011- Spring 2012 Research Assistant, Dr. Lauren Heberle, Dept. of

Sociology, University of Louisville

Major Responsibilities:

- Transcribing and organizing interview data

- Writing biographies of relevant institutions in the research area

Fall 2008- Spring 2010 Disability Learning Assistant, University of Louisville Major Responsibilities:

- Attending lecture and taking notes for students with disabilities

- Tutoring students on class material in private sessions 


\title{
PAPERS UNDER REVIEW
}

Beggan, J.K. \& Pruitt, A.S. Leading, following, and sexism in social dance: Change of meaning as contained secondary adjustments. Submitted to Journal of Leisure Studies.

\section{PAPERS PRESENTED AT PROFESSIONAL MEETINGS}

Pruitt, A.S. "Imagine being in prison: Presentations of teen pregnancy on MTV". Presented at the 2011 Anthropologists and Sociologists of Kentucky meeting at Northern Kentucky University.

Pruitt, A.S. "Emotional labor in a gendered occupation: The care work of the female funeral director." Presented at the 2012 North-Central Regional Meeting of the American Sociological Association, Pittsburg, PA.

\section{PAPERS IN PROGRESS}

Pruitt, A.S. Emotional labor in a gendered occupation. To be submitted to Gender, Work and Occupations.

\section{RESEARCH INTERESTS}

- Qualitative and inductive methods

- Social-identity and culture

- Community-based organizations

\author{
PROFESSIONAL SERVICE \\ 2010-Present Officer of the Social Sciences, University of Louisville Graduate \\ Student Union \\ 2011-Present Committee Member, University of Louisville Arts \& Sciences \\ Graduate Grievances
}

\section{COMMUNITY SERVICE}

2008-2010

2005-2007
Volunteer, Brooklawn, Louisville, KY.

Volunteer, United Community Against AIDS Network, Olympia, WA. Assisted individuals with advanced AIDS in obtaining medication and housing. 


\section{HONORS}

- Alpha Kappa Delta Sociological Honor Society

- Golden Key Honor Society

- Dean's List, University of Louisville

- Outstanding Graduate Student 2012, University of Louisville, Department of Sociology 